\title{
Cikkismertetés: Hogyan változott az iskolázottságnak a várható élettartamra kifejtett hatása Belgiumban?
}

\author{
Article review: How did change the educational effect on life expectancy \\ in Belgium
}

$\begin{array}{ll}\text { Ismertető: } \quad \text { Maródi Ágnes } \bowtie \\ & \text { Szegedi Tudományegyetem Bölcsészettudományi Kar, Neveléstudományi Doktori Iskola }\end{array}$

Ismertetett cikk: Renard F, Devleesschauwer B, Van Oyen H, et al.: Evolution of educational inequalities in life and health expectancies at 25years in Belgium between 2001 and 2011: a censusbased study. Arc. of Pub. Health 77, 6 (2019). doi: 10.1186/s13690-019-0330-8

Beküldve: $\quad$ 2019.10. 07.

doi: $\quad$ 10.24365/ef.v61i1.525

Kulcsszavak: korlátozottság-mentes élettartam; várható élettartam; iskolai végzettség; egyenlőtlenség; Belgium

Keywords: barrier-free life expectancy; life expectancy; education level; inequalities; Belgium

\section{BEVEZETÉS}

A szocioökonómiai státusz terén mutatkozó egészség-egyenlőtlenség csökkentésének kérdése népegészségügyi prioritás, ezért fontos ennek nyomon követése, melynek során a népesség összetételének változásait is figyelemmel kell kísérni. A szerzők a várható életkor és a korlátozottság-mentesen várható élettartam egyenlőtlenségeinek alakulását elemezték az iskolai végzettség figyelembevételével Belgiumban, 2001 és 2011 között.

\section{MÓDSZEREK}

A várható élettartam és a korlátozottság-mentesen várható élettartam szocioökonómiai státuszbeli különbségeinek kiszámításához a 2001-es és 2011-es népszámlálási adatokat, a belga nemzeti nyilvántartásban szereplő halálozási adatokat, valamint a 2001-2013 közötti belga egészségfelmérések eredményeit vették alapul. A tanulmányban a 25 évesen várható élettartamot (life expectancy at age 25, LE25) és a 25 évesen várható korlátozottságmentes élettartamot (disability-free life expectancy at age 25, DFLE25) vetették össze az iskolai végzettséggel (alapfok, középfok, felsőfok).

\section{EREDMÉNYEK}

Mind a nők, mind a férfiak iskolai végzettsége esetén eltolódás figyelhető meg a magasabb iskolai végzettség felé 2001 és 2011 között: a legalacsonyabb iskolai végzettséggel rendelkezők aránya csökkent (férfiaknál 42\%-ról 36,3\%-ra, nőknél 45,4\%-ról 38,2\%-ra), míg a közép- és a felsőfokú végzettségúek aránya mindkét nemnél nőtt. Az eredmények alapján a 25 éves életkor alapján várható élettartam minden iskolai végzettség és mindkét nem esetében nőtt a 2001-es adatokhoz képest, a nőknél kisebb mértékben, mint a férfiaknál, és majdhogynem változatlan maradt az alacsony iskolai végzettségű nők körében. [1. táblázat] 
1. táblázat: 25 éves korban várható élettartam változása 2001 és 2011 között az iskolai végzettség egyenlötlenségeit figyelembe véve

\begin{tabular}{|c|c|c|c|c|c|c|c|c|c|}
\hline Iskolai végzettség & $\begin{array}{l}\text { Várható } \\
\text { élettartam } \\
25 \text { éves kor } \\
\text { alapján, } \\
2001\end{array}$ & $\begin{array}{l}\text { Várható } \\
\text { élettartam } \\
25 \text { éves kor } \\
\text { alapján, } \\
2011\end{array}$ & $\begin{array}{c}2001 \text { és } \\
2011 \\
\text { közötti } \\
\text { különbség }\end{array}$ & p-érték & $\begin{array}{l}\text { Egyenlőtlen- } \\
\text { ség a felső- } \\
\text { fokú végzett- } \\
\text { séghez } \\
\text { képest } \\
\text { 2001-ben }\end{array}$ & $\begin{array}{l}\text { Egyenlötlen- } \\
\text { ség a felső- } \\
\text { fokú végzett- } \\
\text { séghez } \\
\text { képest } \\
\text { 2011-ben }\end{array}$ & $\begin{array}{l}\text { Abszolút } \\
\text { különbség }\end{array}$ & $\begin{array}{l}\text { A különbség } \\
\text { \%-ban }\end{array}$ & p-érték \\
\hline \multicolumn{10}{|c|}{ Férfiak } \\
\hline \multicolumn{10}{|l|}{ Különbségek } \\
\hline alapfok & 50,63 & 51,74 & 1,11 & $<0,001$ & 5,19 & 6,07 & $+0,87$ & $+16,8 \%$ & $<0,001$ \\
\hline középfok & 53,18 & 54,73 & 1,55 & $<0,001$ & 2,65 & 3,08 & $+0,43$ & $+16,2 \%$ & $<0,001$ \\
\hline felsőfok & 55,82 & 57,81 & 1,99 & $<0,001$ & ref & ref & ref & ref & / \\
\hline \multicolumn{10}{|c|}{ Összetett Egyenlőtlenségi Index } \\
\hline $\begin{array}{l}\text { Abszolút Összetett } \\
\text { Egyenlőtlenségi } \\
\text { Index }\end{array}$ & . & . & & & 3,14 & 3,36 & $+0,23$ & $+7,3 \%$ & $<0,001$ \\
\hline $\begin{array}{l}\text { Relatív Összetett } \\
\text { Egyenlőtlenségi } \\
\text { Index }\end{array}$ & . & . & . & . & $6,10 \%$ & $6,30 \%$ & $+0,2 \%$ & $3,30 \%$ & 0,004 \\
\hline \multicolumn{10}{|c|}{ Nők } \\
\hline \multicolumn{10}{|l|}{ Különbségek } \\
\hline alapfok & 57,14 & 57,32 & 0,18 & $<0,001$ & 3,76 & 4,58 & $+0,82$ & $+21,8 \%$ & $<0,001$ \\
\hline középfok & 59,14 & 60,09 & 0,95 & $<0,001$ & 1,76 & 1,81 & $+0,05$ & $+2,8 \%$ & 0,4561 \\
\hline felsőfok & 60,90 & 61,90 & 1,00 & $<0,001$ & ref & ref & ref & ref & / \\
\hline \multicolumn{10}{|c|}{ Összetett Egyenlőtlenségi Index } \\
\hline $\begin{array}{l}\text { Abszolút Összetett } \\
\text { Egyenlőtlenségi } \\
\text { Index }\end{array}$ & & . & & . & 2,32 & 2,38 & $+0,05$ & $+2,2 \%$ & 0,217 \\
\hline $\begin{array}{l}\text { Relatív Összetett } \\
\text { Egyenlőtlenségi } \\
\text { Index }\end{array}$ & & . & & . & $4,10 \%$ & $4,00 \%$ & $-0,1 \%$ & $-2,4 \%$ & 0,696 \\
\hline
\end{tabular}

Forrás: Renard F et al. Evolution of educational inequalities in life and health expectancies at 25 years in Belgium between 2001 and 2011: a census-based study. Arc. of Pub. Health 2019; 77: 6.

A nők 25 éves korban várható élettartama sokkal magasabb, mint a férfiaké, függetlenül az iskolai végzettségtől. A 25 éves korban várható élettartam férfiaknál mindhárom iskolai végzettség esetén magasabb volt 2011-ben: az alapfokú és felsőfokú végzettségúek közötti különbség 16,8\%-kal növekedett (5,19 évről 6,07 évre).

A férfiak körében a 25 éves korban várható korlátozottság-mentes élettartam 4,7 évvel növekedett a magasabb iskolai végzettséggel rendelkezők csoportjában, de a többi végzettség esetén nem változott. A nők 25 éves korban várható korlátozottság-mentes élettartama magasabb volt 2001-ben, mint a férfiaké, az iskolai végzettségtől függetlenül. 2001 és 2011 között a nők korlátozottság-mentes várható élettartama 3,78 évvel csökkent az alapfokú végzettséggel rendelkezők csoportjában, a többi végzettség esetében ez az élettartam forma nem változott.

\section{ÖSSZEGZÉS}

A 25 éves kor alapján várható élettartam minden iskolai végzettség esetében nőtt, a növekedés mértéke azonban nagyobb volt a magasabb iskolai végzettséggel rendelkezőknél, ami a legalacsonyabb és a legmagasabb iskolai végzettségűek közti különbség növekedéséhez vezetett. A legalacsonyabb és a legmagasabb végzettségúek közti különbség a várható élettartam esetében férfiaknál a 2001-es 5,19 évről 2011-re 6,07 évre nőtt (+17\%), míg a nőknél 3,76 évről 4,58 évre emelkedett (+22\%). A nők körében a várható élettartam a férfiakhoz viszonyítva mérsékeltebben nőtt 2001-ről 2011-re, ami a nemek közti különbség csökkenéséhez vezetett. [2. táblázat]

Férfiaknál a 25 éves életkorban korlátozottságmentesen várható élettartam csak a magasan képzettek esetében nőtt, a többi iskolai végzettség 
esetén nem változott szignifikánsan, ami a különbségek növekedéséhez vezetett 2011-re. A 25 éves életkor alapján várható korlátozottság-mentes élettartam nők esetében csökkent az alacsony iskolai végzettséggel rendelkezők csoportjában, míg a közép- és felsőfokú iskolai végzettséggel rendelkezőknél változatlan maradt. 2011-ben a legmagasabb és a legalacsonyabb iskolai végzettségúek közti különbség a 25 évesen várható korlátozottságmentes élettartam tekintetében a férfiaknál 10,4 év, míg a nőknél 13,5 év volt, ami a 2001-es 6,51 év (férfiaknál) és 9,30 év (nőknél) különbségekhez képest a férfiaknál 61\%-os, a nőknél 44\%-os növekedést eredményezett.

2. táblázat: A várható élettartam és korlátozottság-mentes várható élettartamának megoszlása az iskolai végzettség és nem szerint 25, 30, 50 és 65 éves korban, Belgiumban, a 2011-es (5 évvel után követett) adatokból kalkulálva, a belga nemzetiségü lakosság körében

\begin{tabular}{|c|c|c|c|c|c|c|c|c|c|c|}
\hline \multirow[b]{2}{*}{ Életkor } & \multicolumn{5}{|c|}{ Várható élettartam } & \multicolumn{5}{|c|}{ Korlátozottság-mentesen várható élettartam } \\
\hline & $\begin{array}{c}\text { Alapfokú } \\
\text { végzettség }\end{array}$ & $\begin{array}{l}\text { Középfokú } \\
\text { végzettség }\end{array}$ & $\begin{array}{l}\text { Felsőfokú } \\
\text { végzettség }\end{array}$ & $\begin{array}{c}\text { Hiányzó } \\
\text { adat }\end{array}$ & $\begin{array}{c}\text { Az alap- és a } \\
\text { felsőfokú vég- } \\
\text { zettség közötti } \\
\text { különbség } \\
\text { években }\end{array}$ & $\begin{array}{c}\text { Alapfokú } \\
\text { végzettség }\end{array}$ & $\begin{array}{l}\text { Középfokú } \\
\text { végzettség }\end{array}$ & $\begin{array}{l}\text { Felsőfokú } \\
\text { végzettség }\end{array}$ & $\begin{array}{c}\text { Hiányzó } \\
\text { adat }\end{array}$ & $\begin{array}{l}\text { Az alap- és a } \\
\text { felsőfokú vég- } \\
\text { zettség közötti } \\
\text { különbség } \\
\text { években }\end{array}$ \\
\hline \multicolumn{11}{|c|}{ Férfiak } \\
\hline 25 & 51,74 & 54,73 & 57,81 & 48,53 & 6,07 & 37,02 & 42,05 & 47,49 & 35,35 & 10,47 \\
\hline 30 & 47,13 & 49,96 & 52,90 & 43,94 & 5,77 & 32,87 & 37,55 & 42,80 & 30,86 & 9,93 \\
\hline 50 & 29,13 & 31,23 & 33,56 & 26,17 & 4,43 & 18,10 & 21,82 & 24,78 & 15,94 & 6,68 \\
\hline 65 & 17,43 & 18,84 & 20,39 & 15,47 & 2,96 & 10,8 & 12,19 & 13,33 & 9,34 & 2,53 \\
\hline \multicolumn{11}{|c|}{ Nök } \\
\hline 25 & 57,32 & 60,09 & 61,9 & 53,83 & 4,58 & 35,54 & 42,98 & 48,98 & 37,5 & 13,44 \\
\hline 30 & 52,52 & 55,17 & 56,94 & 49,15 & 4,42 & 32,08 & 38,37 & 44,34 & 33,33 & 12,26 \\
\hline 50 & 33,94 & 36,03 & 37,47 & 31,29 & 3,53 & 19,51 & 22,3 & 27,22 & 17,95 & 7,71 \\
\hline 65 & 21,21 & 22,77 & 23,81 & 19,77 & 2,60 & 10,70 & 12,72 & 15,31 & 10,72 & 4,61 \\
\hline
\end{tabular}

Forrás: Renard F, Devleesschauwer B, Van Oyen H, et al.: Evolution of educational inequalities in life and health expectancies at 25 years in Belgium between 2001 and 2011: a census-based study. Arc. of Pub. Health 2019; 77: 6.

\section{TANULSÁGOK A HAZAI SZAKEMBEREK SZÁMÁRA}

Az egészséges életévek számának a növelése fontos egyéni és társadalmi szinten egyaránt, amihez szükséges az iskolázottság, mely összefüggést mutat a várható élettartammal és az egyén egészségi állapotával. Egy átfogó tervet szükséges kidolgozni az egészség terén mutatkozó egyenlőtlenségek kezelése érdekében, különös figyelmet fordítva az alacsony végzettségúek egészségének javítására. 